Opinion Piece

\title{
Brexit, or How to be Serious after the Referendum ${ }^{i}$
}

Tim Beasley-Murrayii

High up in the pantheon of British values-perhaps among those that the Conservative Government wants to be taught to children in schools-is our famed British sense of humour. Everybody, British and foreign, seems to agree that we are the funny man of Europe. If the notoriously humourless bureaucrats of Brussels were to create the post of EU commissioner for jokes, there is no doubt that the job would go to a Brit. Or perhaps: would have gone to a Brit.

It is telling how much difficulty I have with tenses when talking about Britain and Europe. When someone has died, we have difficulty switching from the present to the past. Here, we are not sure whether Britain's membership of the EU has really gone, or whether it is still clinging on and might yet miraculously revive. As I write, the Government has yet to trigger Article 50. Britain's Europeanness is in a coma that we, the electorate, have induced, hovering, like Schrödinger's cat, between life and death, and no-one has dared open the box. It might, of course, be suggested that Britain has always occupied this threshold position in relation to Europe. A passer-by who stands chatting on the doorstep and can't quite make up his mind whether to accept the invitation to come in for a cup of tea, a guest at the end of the evening who lingers in the hallway, unsure whether to stay a bit longer and call a cab or run for the last tube. But now, Britain is the European Union's living dead, its old nag at the knacker's yard, dumbly waiting for the merciful bolt of Article 50 . This situation - the zombification of Britain in Europe, one might call it-is likely to last for years 
and, in so many areas of public life, one can only begin to imagine its stultifying and uncanny effects. But, on an emotional level, it leaves one in limbo, not knowing whether one ought to be in mourning, not knowing whether to laugh or cry.

Many Remainers (remoaners, as the pro-Brexit press now calls them) have already shed tears over Brexit. On the morning of the result, I took my children, as usual, on the District Line from their East London home to their school, the French lycée, in South Kensington. Sitting between them in a curiously tense and silent tube carriage, I had to explain to them-in French, quietly but with intensity-what had happened, why that decision went against values that I hold dear and values that they ought also to cherish, but also reassure them that their future would nonetheless be bright. Brexit for children. Coming from a middle-class household and with a privileged background, their future will be bright and, in practical terms, as young holders of both British and French passports, Brexit will affect them least of all. Certainly, their future will be brighter and be less materially affected by Brexit than the children of those working-class Leave voters in the postindustrial towns and cities of England and Wales who rightly felt that the modern world gives them a wrong deal but wrongly were led to lay the blame for these grievances on migration and the European Union. And certainly my Franco-British children are less in need of reassurance than, say, the children of Polish families in Britain whose situation the result of the vote throws into existential uncertainty and who are in the firing line of postReferendum racism. This said, explaining what is wrong with the world-its injustices and idiocy - to children is a serious matter that brings a depth of emotion into play. Standing in the middle of the carriage, a youngish woman-not obviously French-looking, a normal, probably British Londoner, clearly listening to and understanding what I was saying - began silently to weep. 
Boris Johnson's first post-Referendum column for The Telegraph was a piece that dripped with disdain for the largely young, largely metropolitan pro-European centre-left and displayed a mind-numbing degree of delusion about his and Britain's ability to have its Brexit cake and eat it too.iii In it, Johnson suggested that the immediate reaction of Remainers to the vote was reminiscent of the "hysteria" and "contagious mourning" that swept the country in reaction to the death of Princess Diana. There is lots to disagree with in this suggestion. To accuse Remainers of irrational anxieties and irrational outpourings of collective emotion jars substantially in the context of a Leave campaign that had been built precisely on irrational fears - of migrants, of modernity and of so much else - a Leave campaign that had fostered a dangerously contagious form of collective emotion and that had explicitly disdained reason and the cool assessment of experts. Nevertheless, Johnson was perhaps onto something. There was something indulgent, something false, something over-privileged, something unmistakably pathetic in the emotional excesses-tears, anger, love- of the Remain protesters on Trafalgar Square shortly after the referendum with their "We love EU" placards. Oddly, less than the genuinely popular tears shed over Diana's death, these tears brought to my mind the Queen's tears at the decommissioning of the Royal Yacht.

If you were looking for the Hauptquartier of the liberal, metropolitan, remain-voting elite, you could do worse than go to University College London. UCL_or, as its strapline has it, "London's Global University" -is also deeply European in ideological and practical terms. On the one hand, its so-called radical tradition is viscerally internationalist-indeed, Bentham, UCL's spiritual founder, coined the very term "international." On the other hand, UCL, like the rest of Britain's Universities, benefits enormously from European mobility of staff and students and from European funding and collaboration in research. If London as a 
whole voted to remain, the figure for UCL (those of its massively international staff and students who were eligible to vote) must have been near $100 \%$. So when, having dropped off the children at school in South Kensington on the day after the night before, I walked through Bloomsbury and on into the main quad of $U C L$, I found an institution in shock and in mourning. Now, if you had walked the same route into UCL's quad a few weeks back, in the midst of the Referendum campaign poisoned by xenophobic and racist discourse about migrants, and if you had looked up to the flagpole on top of the classical dome of UCL's main building, a flagpole where often the rainbow colours of the LGBT+ movement fly, you would have seen a curious silver banner. This banner was an art project by UCL Slade students, "The New European Flag," made out of the foil blankets used to drape refugees from Syria who wade ashore on the Greek of island of Lesbos. ${ }^{i v}$ Raising the flag, its makers tell us, was "an attempt to create and disseminate a powerful social and humanitarian message marked by solidarity." While the flag was raised on 9 June, moreover, a string quartet and singer performed Beethoven's "Ode to Joy." On the morning, I seriously expected to see the New European Flag at half-mast.

As we know, the results of the Referendum tell us that many who voted Remain were the educated and the experts and that their strongholds were the university cities of London, Bristol, Oxford and Cambridge, Edinburgh and Exeter. These Remain-voters are those who benefit (or "were" and "benefitted" - the awkward question of tense, again) most and most obviously from European free movement for study and employment. As with my children, this mobile, educated elite will survive and most likely still prosper in postBrexit Europe. The few post-Brexit obstacles on their golden path will be as nothing compared to the obstacles that face working-class Leave voters. So, while, like the Slade students, I want to see a Europe that combines the tradition of Beethoven with an openness 
to a wider world and that responds to, for example, the Syrian refugee crisis with compassion and with action, while I understand and share in their anger and grief at Britain's decision, the radical disconnect between their "New European" values and the values of an electorate beyond the metropolis is a cause of deep anxiety. What's more, their foil flag, their Ode to Joy, their grief that is also mine, all this is - I say with bitternesssomewhat risible. Just as - and with no less bitterness I have to agree in part with Johnson, here-there was something risible about the Remainers on Trafalgar Square who so strikingly demonstrated the truth of two clichés: "there's no use closing the stable door after the horse has bolted" and "you only appreciate what you had once you've lost it." So what about laughter after the Referendum? On the second weekend after the Referendum, we went to lunch at the house of two of my UCL colleagues. Needless to say, they, and the other lunch guests, were passionate Remainers. Among these other guests was a cartoonist whose work regularly features in The Guardian and elsewhere. So, yes, not just Guardian readers but worse... Conversation turned to the task of the cartoonist postBrexit. The Tory leadership drama, with its Shakespearean stabbings, had yet to unfold. But we agreed that, just as these events have given Britain's dramatists and screenwriters material to work on for decades to come, so the cartoonists of Britain must continue with their valued work, even if it is a matter of "laughter through tears," in Chekhov's memorable phrase. Perhaps the best example of cartoonists doing exactly that comes not from Britain but from the US. The first cover of the New Yorker after the Referendum was a brilliant reimagining of Monty-Python's Ministry of Silly Walks that pictured bowler-behatted and pinstriped Brits obliviously silly-walking their way over a precipice. Here, where the original sketch was gentle satire on British bureaucratic idiocy and harmless eccentricity, the cartoon redirected this satire to target an idiotic eccentricity that had turned suicidal in its 
revolt against Brussels bureaucracy. Monty Python, those most British of comedians and every foreigner's favourites, had been co-opted by foreigners to point out that, no longer the funny man of Europe, Britain had made itself a laughing stock. A corresponding British sense of humour failure came over me in the underground a few days after the results came through. A group of Germans, young professionals in their thirties, were further down the carriage, laughing and joking loudly. As I looked over towards them, straining but failing to hear what they were saying, two things occurred to me as I felt an unmistakable wave of disapproval rising inside. First, surely, post-Referendum, these laughing Germans might be aware that some people, those forty or so percent of Londoners who voted "out," might be inwardly scowling and wishing them to go home. But, more seriously, an uneasy and slightly paranoid part of me felt offended by the possibility that they might have been laughing at us, at our stupidity and the mess that it has got us into. If a relationship is going to stay healthy, it's a truism to say that, while your partner may criticise his or her family, they are likely to get offended if you do so. It is at moments like these, in our tendency to accept criticism, to laugh or, on the contrary, to be offended, that our emotional responses tell us something about who we are. What I realised in the tube was that I am no less British than I was before the Referendum.

It is a journalistic commonplace (and by now a lazy one), when addressing any disastrous turn in public life, to quote or misquote Marx in the Eighteenth Brumaire: "Hegel remarks somewhere that all great world-historic facts and personages appear, so to speak, twice. He forgot to add: the first time as tragedy, the second time as farce." ${ }^{\prime v}$ There has been plenty of tragedy and plenty of farce in the Referendum campaign and its aftermath. Yet, for the most part, it has been difficult to draw any clear line between the two: any tragic quality of events has been undermined by their farcical nature, any farce been tinged with the 
bitter taste of tragedy. But, if one were to assert farcical repetition of some previous tragedy, then it is by no means clear what that previous tragedy might be. One might suggest that this inability to tell what particular past we are fated to repeat is evidence of the way that our contemporary world has come loose from its historical moorings. This might also explain why those few and muted appeals to History that were made during the campaign, particularly by the Remain side, found so little traction with the electorate. This stands in contrast to the traction generated by the Leave side and their appeals to an ahistorical and mythical British past. Nonetheless, if there is something in the suggestions that an apt historical parallel for the contemporary rise in xenophobic populism, in Britain and in Europe more widely, is the collapse of democracy in Europe in the 1930s in the face of similar forces, then our farcical present is far from a laughing matter.

As far as tragedy it concerned and looking back to Aristotle: this whole shoddy business has abounded in different instances of hamartia (tragic error, tragic flaw) and the resultant peripeteia (reversal of fortunes), both for individual protagonists who-have been brought low, and for the country as a whole, as Great Britain, along with its credit rating and its place in international esteem, slips towards becoming Little Britain, if not Little England (and Wales). What has so far been lacking on the part of any of the political protagonists, at least in public, is any moment of anagnorisis (discovery, recognition), the moment when they recognize the reality of the situation in which they find themselves and the error of their actions. Tellingly, Aristotle judged the presence of anagnorisis, this element absent in Brexit, to be a mark of a superior tragedy. On the part of the electorate, a faint and immediate equivalent of anagnorisis has been those expressions of ther's regret on the part of some Leave-voters. True recognition will most likely be a much longer and more painful process. Where parallels with an Aristotelian conception of tragedy break down, 
however, is over Aristotle's definition of tragedy as an imitation of characters of a higher type-kings, heroes, great men. The protagonists of this drama-above all, Johnson, Nigel Farage (leader of UKIP) and Michael Gove (now-ex-Minister of Justice)-are so tawdry, so small and transparent in their self-seeking mendacity-that to suggest that there is anything tragic about their actions and their fates would be utterly false. Comparisons with Shakespeare, in this his four-hundredth anniversary year, might be nearer the mark. Here again, however, Gove, say, in his cowardice and moral liability shrivels when compared to Macbeth, "valour's minion," and to the moral seriousness of the conspirator, Brutus; Sarah Vine (Gove's columnist wife), with her leaked email and Daily Mail prejudice for daggers, makes for a cut-price Lady Macbeth. No, Brexit might be more correctly be viewed as the degenerate offspring of the tradition of Revenge tragedy-personal vendettas amongst the elite, on the one hand, and the revenge of the so-called "left behind" against the elite as a whole, on the other. And here, as in a good Revenge tragedy, the avengers are also likely to end up dead.

If it is wrong to talk about the Referendum and its aftermath in terms of tragedy, it is certainly true that seriousness has been lacking and that seriousness, as a virtue, has not been much prized. On the contrary, what we have witnessed is ill-placed comedy that has turned deadly serious. Johnson and Farage: this pair were clowns whom the serious elite did not take sufficiently seriously until the joke that was the idea of leaving the EU had become a serious proposition. In the case of Johnson, as we know, his comic persona was the result of careful and serious calculation and cultivation. Now, I have no intention here to add to the piles of character assessments and character assassinations of Johnson and Farage, the pantomime villains of this particular piece. Nonetheless, a perspective from my schooldays might possibly shed some light. In the case of Johnson and his near contemporary, 
Cameron, so much of their character and fundamental disposition - that have, in large part, landed us in this mess - can be traced, albeit generically, to their schooling and their thorough-going institutionalization in the ways of their class.

The chief values that Eton inculcated in its inmates were not those of public service and sincerity - far from it. The chief value, articulated negatively, was not being keen. To be labelled keen - a frequent term in the Etonian vocabulary - was to be on the wrong end of a damning character indictment. The Etonian is expected never to be keen; he aspires to success that appears effortless. This value holds in all spheres of Etonian life: in terms of social success and popularity, in academic life where brilliant results have to be achieved without evidence of work, and even on the sports-field where trying too hard or caring too much is seen as a serious moral defect. On the terrain of sport, cricket is the best expression of this: the elegance and lazy effortlessness of a neatly timed on-drive, aristocratically struck in the manner of David Gower. (I don't know much about Johnson's prowess on the cricket field. Interestingly, though, Johnson decided that the most important thing to do on the day after the Referendum was to put on his whites and play in a charity match; I imagine him to be a rather rambunctious, not particularly accurate medium-fast bowler.) From the psychological point of view, it would be possible to explain this all-encompassing value in terms of the need to keep apart exterior appearances from a protected interior in the midst of the systemic, psychical violence that is inflicted on children in boarding school life. From the sociological point of view, one might legitimately argue that the institution of antikeenness is only fitting for a class that needs, structurally, to obscure its own unjust advantages. At Oxford, too, to achieve without appearing to put in any effort was the most valued thing of all. The concept of "a Gentleman's third" is well known (a low final degree classification that is the result of too much time spent on sport and socializing); less well 
known but far more highly prized is "the Gentleman's first" (a top degree classification that results in the same circumstances).

Returning to the matter at hand: the Etonian and Oxonian value of not appearing keen provides a useful heuristic when looking at the class and the individuals that it has contributed to shape and their behaviour in politics and public life. The fundamental split between appearance and interior, inherent in an ethic of anti-keenness, is one that Machiavelli approved of. If, as Machiavelli argues in The Prince, "the great majority of mankind are satisfied with appearance, as though they were realities and are often more influenced by the things that seem than by those that are," then the aspiring leader, in Machiavelli's view, must be able precisely to cultivate appearances, to "appear merciful, faithful, humane, religious, upright, and to be so, but with a mind so framed that should you require not to be so, you may be able and know how to change to the opposite."vi Now, Machiavelli in The Prince is addressing rulers and we can argue with him about whether these really are qualities we, as the ruled, would wish for in those in authority. But it is obvious that such a mode of political behaviour is inconsistent with a politics of conviction and sincerity and is entirely consistent with Johnson's lack of conviction, his deceitfulness, his shallowness, and his opportunism. And it is also clear that Johnson's mask of cartoonish buffoonery is no more than that: a cynically calculated way to appear not to be keen and to hide his gnawing and violent personal ambition - that surely further masks some deep sense of personal inadequacy, some essential void, but that is mere speculation. What is not speculation is the fact that Johnson's Machiavellian clowning has had a deeply corrosive effect on the quality and seriousness of our public discourse and that the bad joke of his deciding to support Leave-something that, in a characteristically Etonian way, he scarcely 
seemed to believe in or care about-has been disastrous for Britain and for Europe. The sooner this Etonian class in its entirety is swept out of Britain's seats of power, the better.

And as for Johnson? In our Early Modern History classes at school, we learned about Golden Age Spain and came across a figure called Olivares. All that one learned about him was that he was a sort of off-brand Richelieu and that his name always came with the epithet "oleaginous." Oleaginous Olivares. As I write (quite literally: Britain may or may not be entering a recession but the one thing that it is overproducing is news), Boris Johnson has been appointed Foreign Secretary in the cabinet of the new Prime Minister, Theresa May, something that will only contribute to Britain's growing reputation as the laughing stock of Europe. Nonetheless, it is my sincere wish that, in the long run, History grants Johnson an epithet no less disparaging than that of Olivares and that his name is forever consigned to some inglorious footnote, plaguing only certain sorts of schoolchildren.

Let us try and put anti-keenness, with its insincerity and its corrosive effect on seriousness, into a European context. It is, of course, to a certain extent, a British value more broadly. It-might be seen as the flipside of that otherwise positive phenomenon of British self-deprecation and capacity for self-irony. Nonetheless, a similar phenomenon exists elsewhere, above all, as the reference to Machiavelli indicates, in Italy, where the language even has a proper word for it: sprezzatura. Machiavelli's Prince appears to have been circulating amongst educated Florentines from around 1513. Baldassare Castiglione's Book of the Courtier, that introduced sprezzatura as a word and a concept to European culture, was published in 1528. Sprezzatura, which Castiglione defines as a "certain nonchalance, so as to conceal all art and make whatever one does or says appear to be without effort and almost without any thought about it" is the primary virtue (if virtue is the correct term) of the ideal courtier that enables him to conceal his inner desires thoughts 
and feelings behind a veil of feigned nonchalance. ${ }^{\text {vii }}$ Johnson and Berlusconi have frequently been compared; it is difficult to know who would win in a competition of despicableness, but Berlusconi is perhaps a little more vulgar in the way his ludicrous clownishness hides a lust for power. Whatever the case, it is tempting to see in Berlusconi's façade of buffoonery a bastard child of Renaissance deviousness that, via a different route, Johnson has also inherited. Beyond Italy, however-and here I am dealing with sweeping cultural generalizations - seriousness seems to have the upper hand. It would be wrong to mistake the stereotypical French concern with elegance for a lack of seriousness. The tenor of public life in France is such that there is little attempt to hide the seriousness that is a necessary component of success. And as for Germany: well, here the stereotype of German seriousness is definitely rooted in truth. Views from Europe of our British self-inflicted plight contain a certain degree of solidarity and concern. It is no wonder, however, that these views of developments in Britain and of our calamitous abandonment of seriousness also include disparagement, ridicule and a certain degree of Schadenfreude.

One cannot attribute the disorienting reversal of the comic and the serious to the EU Referendum alone. Such a reversal has been a feature of British public life for a while now. Not only have politicians become comedians; the same path has been followed by the world's best-known philosopher in whose work the balance of serious and comic has shifted from the former to the latter in recent years. In what other terms can one characterise Slavoj Žižek whose performances, with their sexist gags and parodic selfcaricature, have more in common with stand-up comedy than philosophy and whose absurd conclusions (Return to Hitler/Lenin/Stalin! Or whichever totalitarian despot is du jour) work best as Surrealist one-liners? The serious has become comic and the reverse is also true: in Ed Miliband's drab and dispiriting election campaign, one of few incidents of note was the 
rallying of former heroin-addict, love God, and comedian, Russell Brand, to the Labour cause.

How to respond, seriously, to this conflation of the serious and the comic? Written in the very darkest times of the twentieth century, Bertolt Brecht's play of 1941, Arturo Ui, was a response to a threat that was, doubtless, far more grave than the crisis in which we find ourselves right now. A savage satire on the rise to power of the Nazis, it portrayed Hitler as a comic-book gangster, running a crooked racket in cabbages in interwar Chicago. Brecht's satire (though arguably not very funny) took the same route as Chaplin's Great Dictator in attempting to counter all that is wrong with ridicule that both belittles and exaggerates. In so doing, however, as critics have argued, this approach has a tendency to trivialize and obscure the evil that it combats. Now, I want to make it absolutely clear that I am not falling victim to Godwin's law and making a facile and histrionic parallel between the rise of Hitler and the victory of the Leavers in the Referendum. What is at stake here are discursive tactics. In some senses, Johnson (and to a less extent Farage) presented a more slippery target than the one that faced Brecht. What to do when one's target is successful in conflating the comic and serious? Respond to the element of seriousness with satire and ridicule? Or show that behind the buffoonery lies a serious threat? In the end, neither approach seems to have worked.

Since the late 1980s, journalists and academics have been talking about the "postfactual" era and the "post-factual" politics that characterise it. These ideas, however, are not new. Post-factual politics are most evident in times of disagreement and conflict, which indicates that the post-factual idea is simply an updating of Senator Hiram W. Johnson's dictum, back in 1919, that "the first casualty when war comes is truth." There is no doubt, however, that the post-factual nature of era has emerged more clearly than ever in the 
course of the Referendum. Depending on where you stand, you are likely to attribute the fostering of the post-factual nature of things to one side or the other: to the Remain side with their hyperbolic statement of Project Fear, to the Leave side with their mendacious presentation of Britain's financial contribution to the EU, of the effects of migration, and with their assertion that outside the EU Britain will still be able to benefit from the single market, while being able to opt out of the commitment to freedom of movement. Where I stand ought to be clear. This said, in the Referendum campaign, an even earlier victim than truth was the seriousness that is always necessary to contend that truth matters. This, I think, is new and plays a part in one striking success of the Leave campaign: not only have they been successful in devaluing the pound, they have also successfully devalued the currency of expertise. Gove's claim in his Sky TV interview of 3 June that "people in this country have had enough of experts" was possibly the biggest joke of the entire campaign. Not least among the many ironies in this statement was that it came from Gove, apparently the intellectual heavyweight of the Leave campaign. (Gove's claim was part of the postfactual continuum in which a succession of members of the elite claimed not to be part of, and to be standing up to, the elite.) In the face of Gove's unlikely seizing of the populist and anti-expert high ground, the Remain campaign seemed to be caught in the headlights. Try as they might, they could not successfully counter this extraordinary gambit, whether with ridicule (Cameron's various car-maintenance metaphors) or with a re-statement of the seriousness of their case. Seriousness simply wasn't serious anymore. The absolutely ironic was absolutely impervious to irony.

As an expert in a range of things, albeit things of questionable practical value (the thought of Walter Benjamin, Czech and Slovak literature, Structuralism, and so on), I take personally the attack on expertise and on seriousness. My ten-year-old son has picked up on 
the anti-expert spirit of the day, joking (or at least, I think he was joking) that "people don't want to listen to your sort anymore." Nonetheless, rather than simply dismiss it, I think that there is an imperative for experts like us to treat this assault on our seriousness entirely seriously. What stands behind it and in what sense might it be right? This is exactly the same imperative as the one that says that we need to take the Leave voters' concerns about migration seriously. Taking their concerns about migration seriously does not mean saying that they are right when they to say that migration is the cause of their problems. But it does mean recognising that they have problems, the cause of which they wrongly ascribe to migration. For what it's worth, this is (Hegelian and/or Marxist) dialectics, Aufhebung in action: the anti-migration proposition contains a truth (there are problems) and an untruth (migration is the cause) that stand in contradiction. Resolving these contradictions raises the original proposition onto a higher plane (that of rationally oriented political action, now directed, say, against the policies of austerity), preserving the true element, and cancelling out the false.

At first sight an unlikely ally of populism, someone who may help us to understand the truth in the anti-expert proposition is the German-Jewish-American thinker, Hannah Arendt, a thinker on whom, I suppose, I am an expert. As Roger Berkowitz of the Hannah Arendt Center at Bard College has pointed out, also in connection to Brexit, Arendt, particularly in the 1960s and in her writings on US government at the time of the Vietnam war, repeatedly warns of the dangerous role played by experts and elites with their arrogance and shortsightedness. The problem with these experts, for Arendt in On Violence, was that they prided themselves on their pure rationality, reserving any passion for the abstraction of their theories to which they were more than willing to sacrifice any inconvenient facts. Moreover, Arendt argues further, the problem that arises when experts get together and 
assert the iron rule of theory is not simply that they may be wrong-that they might be deluded-but that they might be dangerous:

The danger is that these theories are not only plausible, because they take their evidence from actually discernible present trends, but that, because of their inner consistency, they have a hypnotic effect; they put to sleep our common sense, which is nothing else but our mental organ for perceiving, understanding, and dealing with reality and factuality. viii

Europe has always been, Berkowitz argues, in too large degree the dream of experts. Its utopia has always had too great a technocratic character. Its expert-driven politics has too often neglected the fact that politics is not merely a matter of abstract expertise but of living, feeling men and women. In events such as the Brexit vote, Berkowitz suggests, these men and women are telling us of the pain and dissonance of their everyday lives and "elites are coming to see that their beautiful dream of a cosmopolitan, post-industrial, and technological utopia is bumping into a resistant reality." ix The challenge, then, for us experts is to develop a new form of expertise, one that is not arid, one that listens to human beings and hears their cries of pain, that is in dialogue with their needs and desires. If the European cult of expertise has put our collective common sense to sleep, then the Brexit vote needs to function as a wake-up call, a call for a new sort of seriousness, not the old, arid seriousness of mere expertise, but rather a new seriousness, inflected with imagination and even humour.

Even the most ardent pro-European has to admit that an element of humour has often been lacking in the European Project. My much valued colleagues in the German 
Department at UCL put together a few years ago a volume of worthy essays on the role of humour in German culture. They were, of course, absolutely aware that such a gesture embodied all the clichés of heavy seriousness for which Germans and Germanists are generally known. But Europe, a project so often led by Germans, needs lightness, needs humour, needs imagination, needs hope to counter its perhaps otherwise determining tendencies to opposite qualities. Europe must make its arguments for itself in terms that go beyond the abstract terms of economic rationalism and beyond the po-faced pieties of post-war pacifism.

One voice that was too little heard in the Referendum campaign was that group of committedly pro-European leftists, Greens and other progressives who united under the banner of "Another Europe is Possible." This voice was drowned out by the warning cries of Project Fear, on the one hand, and, paradoxically, by the deafening silence of Jeremy Corbyn and his indifference, even hostility towards Europe, on the other. In the wake of the Brexit vote, there is now a belated call for a new seriousness but not of the sort that I have just described. This seriousness emanates from two sources: first, we have the seriousness of the new Prime Minister and her stolid Anglican values. This, insofar as we know, seems to be little more than conscientious stubbornness: her record suggests that her idea of listening to people is best articulated by her championing of a Snooper's Charter. And second, we have the doctrinaire and no less stubborn seriousness of Jeremy Corbyn, Momentum with their ideological purism and inability to listen to anybody other than their own kind. Despite the depressing turn of events, of which this new situation is a part, in a political and continental landscape that looks increasingly barren, let us nonetheless imagine, and imagine seriously, that another Europe is possible. 
$\underline{\text { Notes }}$

' This piece was written in the three weeks that followed the UK referendum on EU membership, held 23 June 2016.

ii Tim Beasley-Murray, School of Slavonic and East European Studies, University College

London, Gower St, London, WC1E 6BT. t.beasley-murray@ucl.ac.uk

iii http://www.telegraph.co.uk/news/2016/07/03/tory-candidates-need-a-plan-for-brexit-heres-mine-in-5-points/.

ivhttps://www.ucl.ac.uk/news/news-articles/0616/090616-new-eu-flag-art-installation

$\checkmark$ Karl Marx, The Eighteenth Brumaire of Louis Napoleon in Karl Marx and Friedrich Engels, Selected Works in Two Volumes, Moscow: Foreign Languages Publishing House, 1962, p. 247.

vi Niccolo Machiavelli, The Prince and the Discourses, New York: Modern Library, 1950, p. 182

vii Baldassarre Castiglione, The Book of the Courtier, New York: Norton, 2002

viii Hannah Arendt, On Violence, San Diego: Harcourt, 1970, p. 8.

${ }^{i x}$ https://medium.com/amor-mundi/the-experts-meet-reality-1304d0db760\#.gouooebn2. 